palate. The condition was quite inoperable, and it was thought to be useless to employ radium; but in view of his long journey with this object it was obviously advisable to give him the treatment; and from this he appeared to get some temporary relief. There was some slight enlargement of the cervical glands, but these did not increase in size. The heart was normal. There was general bronchitis on admission, but this cleared up, though there were often some rhonchi over the root of the right lung. There was constantly albuminuria associated with cedema of the feet, at first transient and mainly after he had been up, and slight purpura on the hands. The specific gravity of the urine varied from 1002 to 1022 . Casts were not found. There was never any fever, relatively little pain, and weight was remarkably maintained. On admission the weight was 7 st. $4 \mathrm{lb}$. and 4 days before death $7 \mathrm{st} .4 \frac{1}{2} \mathrm{lb}$. The liver and spleen were never found to be enlarged. In June cedema of the legs became more prominent and the albuminuria increased. In July there was not much change until the 17th, when he collapsed and was in great pain. The right leg became livid and cold. He died the next day.

At the necropsy, performed by Dr. R. S. Trevor, there was very extensive carcinomatous invasion of the tongue and soft palate, but no secondary growths or gummatous lesions in any part of the body. The inferior vena cava, the right external iliac and the right femoral veins were distended with recent ante-mortem blood-clot. The right leg from the knee downwards was swollen, bright-red in colour, and showed commencing gangrene. The heart, $8 \mathrm{oz}$, was small and showed brown atrophy. The intestines, kidneys, spleen, and adrenals were amyloid. The liver did not give any amyloid reaction with iodine. Except for the lardaceous change the adrenals appeared healthy.

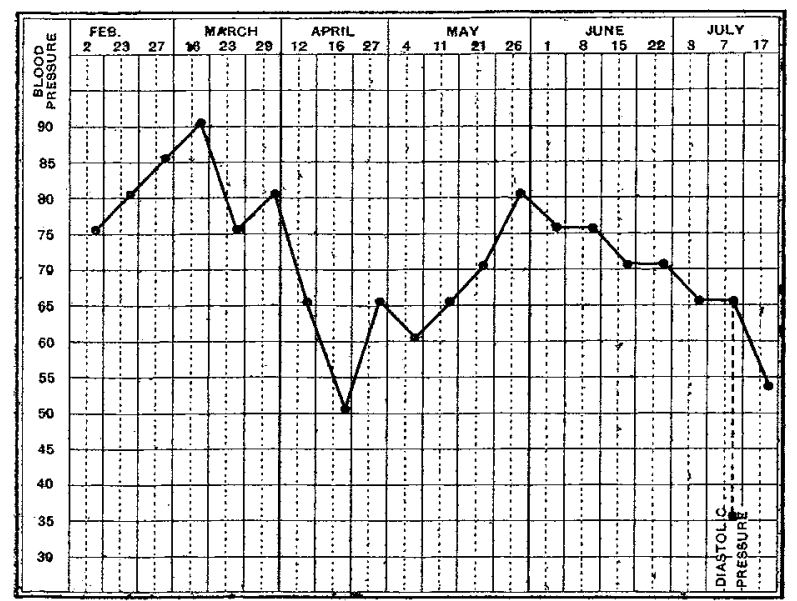

Chart of blood pressure.

Remarks.-The persistent low arterial blood pressure was presumably due to the general asthenia and the amyloid disease, and is unique in my experience, as $\mathrm{I}$ have not seen a blood pressure as low as $70 \mathrm{~mm}$. $\mathrm{Hg}$ except in cases of advanced Addison's disease and in cardiac failure shortly before death. In otherwise healthy persons during the fever of pneumonia I have seen a systolic blood pressure of $80 \mathrm{~mm}$. $\mathrm{Hg}$. As is shown on the chart, the diastolic blood pressure taken by the auscultatory method on July 7 th, ten days before the final collapse, was $35 \mathrm{~mm}$. $\mathrm{Hg}$, with the normal difference of $30 \mathrm{~mm}$. between the systolic and diastolic pressures.

Upper Brook-street, $W$.

The Price of Drugs.-The Pharmaceutical Committee who are advising the Government on the question of the rise in price of various drugs, are holding frequent meetings. The committee consists of Messrs. Edmund White, E. T. Nethercoat, C. A. Hill, John C. Umney, and IT. J. L. Woolcock. Information is in the hands of the committee to the effect that the prices of certain drugs are inflated by reason of the action of particular dealers; and recommendations will probably be made that the Government should exercise its powers under the recent Act in order to prevent such inflation.

\section{đlinital a dotes:}

\section{MEDICAL, SURGICAL, OBSTETRICAL, AND THERAPEUTICAL.}

\section{A CASE OF GANGLION OF RING FINGER.}

By M. C. S. Luawrance, M.B., B.CH. Vict.

THE following case may prove of interest to the readers of THE LANCET.

A woman consulted me some months ago for severe pain in the ring finger of her right hand, which commenced at the tip and spread up her arm, and was so severe as to wake her up at night. It would last several hours, and always commenced with a knock or blow of some sort. She had had the trouble for years, but only lately had it become at all acute.

On examining the finger I could find nothing abnormal in its size, but it was very tender to the touch at the extreme tip, and the nail presented a curious appearance, being raised down the middle by a longitudinal ridge exactly like the ridge produced by folding a piece of paper. I suggested removing the nail, and as she was willing I did so under quinine and urea hydrochloride local anresthesia and found a small ganglion at the very insertion of the extensor tendon. I scraped this out with a small spoon and she has been completely cured. The skin of the finger sloughed rather badly where I had made the injection, but by using scarlet-red ointment she had quite a good scar and completa movement in her finger.

I discovered later that this particular anæsthetic is apt to cause sloughing where the connective tissue is not abundant, and that it would have been better to have used cocaine. It seems to me a very rare condition to find a ganglion in such a position, and also very curious that it should have been the cause of so much suffering.

Earlestown, Lancs.

\section{A FAMILY HISTORY OF POLYDACTYLISM.}

By A. Banks Raffle, M.D. Durh.

THE following family history of polydactylism presen's some feotures of interest.

A woman having an extra finger on each hand married. She had eight children, none of them showing any abnormality of this kind. One of her daughters had 12 children. Of this family the eldest son and the eldest daughter, the first and third children respectively, both showed the same deformity as their grandmother. The son had two boys, both of whom reproduced the abnormality; the daughter had two female children, one of whom had an extra phalanx. None of the collaterals presented anything of the kind.

This case is in marked contrast to the one reported by me some years ago, in which the polydactylism appeared in one generation without any history in the family, the five older children all showing it, whilst the youngest did not. A note on these two cases from some of the profession who make a speciality of these matters would be of interest.

Red Lion-street, W.c. 